\title{
Emil du Bois-Reymond vs Ludimar Hermann
}

\author{
Gabriel Finkelstein \\ Department of History, CB 182, University of Colorado at Denver, P.O. Box 173364, Denver, CO 80217, USA
}

Received 15 November 2005; accepted after revision 15 February 2006

Available online 17 April 2006

\begin{abstract}
This essay recounts a controversy between a pioneer electrophysiologist, Emil du Bois-Reymond (1818-1896), and his student, Ludimar Hermann (1838-1914). Du Bois-Reymond proposed a molecular explanation for the slight electrical currents that he detected in frog muscles and nerves. Hermann argued that du Bois-Reymond's 'resting currents' were an artifact of injury to living tissue. He contested du Bois-Reymond's molecular model, explaining his teacher's observations as electricity produced by chemical decomposition. History has painted Hermann as the wrong party in this dispute. I seek to set the record straight. To cite this article: G. Finkelstein, C. R. Biologies 329 (2006).
\end{abstract}

(C) 2006 Académie des sciences. Published by Elsevier SAS. All rights reserved.

\section{Résumé}

Cet essai rappelle une controverse entre un pionnier de l'électrophysiologie, Emil du Bois-Reymond (1818-1896), et son élève, Ludimar Hermann (1838-1914). Du Bois-Reymond proposa une explication moléculaire des faibles courants détectés dans les muscles et les nerfs de la grenouille. Hermann argumenta que les «courants de repos» de du Bois-Reymond représentaient des artefacts dus à la lésion du tissu vivant. Il contesta le modèle moléculaire de du Bois-Reymond en expliquant les observations de son maître par une électricité produite par décomposition chimique. Dans cette querelle, l'Histoire a dépeint Hermann comme partisan de la mauvaise cause. Mon souhait est de rectifier cet épisode. Pour citer cet article : G. Finkelstein, C. R. Biologies 329 (2006).

๔ 2006 Académie des sciences. Published by Elsevier SAS. All rights reserved.

Keywords: History; Physiology; Germany; Controversy; 19th Century

Mots-clés : Histoire; Physiologie ; Allemagne ; Polémique; XIX ${ }^{\mathrm{e}}$ Siècle

\section{Introduction}

This is a story of a controversy in the history of neurophysiology. Most tell it as follows: a vain and powerful scientist, Emil du Bois-Reymond, trains a bril-

E-mail address: gabriel.finkelstein@ @udenver.edu (G. Finkelstein). liant but hapless student, Ludimar Hermann. Hermann proves his teacher wrong. For this sin du Bois-Reymond banishes him from his laboratory. Hermann eventually vindicates himself, and science returns to truth.

My narrative contests this account. Du Bois-Reymond never abused his authority; instead, it was Hermann who lacked respect. Du Bois-Reymond's resistance to Hermann's theories stemmed less from pride than from an understanding of the limits of science. 


\section{Background}

Emil du Bois-Reymond, a nineteenth century physiologist best remembered for his mechanistic view of life and for his essays on science and culture, was born into the Bildungsbürgertum, that elite and somewhat anxious social class central to discussions of modern German society [1]. His parents were about as well established as was possible for Bürger in Biedermeier Berlin. His father, a poor Swiss Huguenot, had worked his way through the ranks of the foreign office until he became court counselor for the affairs of Neuchâtel, a position that he held until his early retirement in 1848 when revolution gained the canton independence from the Prussian crown. His mother had an even better pedigree from one of the oldest and most prominent of Berlin's Huguenot families: her great-great-grandfather had been the city's first established silk dyer, her grandfather was director of Berlin's Academy of Fine Arts and the city's most famous engraver, and her father was pastor of the French church, librarian to the King, and director of the state artists' guild. With such breeding du Bois-Reymond received an outstanding education, accompanying his father in Switzerland on official tours of inspection, learning to draw from his aunt, polishing his French style at home, and mixing with the wide circle of his family's friends and relations. To complete his studies he attended the Französische Gymnasium and the University of Berlin, two of Germany's best schools, where he learned a broad range of academic subjects before switching to the faculty of medicine in his sixth semester. In 1841, his advisor asked him to look into Carlo Matteucci's treatise on animal electricity. This he did - in fact, du Bois-Reymond spent the rest of his scientific life looking into the topic. The first two volumes of his Investigations in Animal Electricity appeared in 1848 and 1849 and ran over 1400 pages; in 1884 he published a third volume to this truncated masterpiece [2]. This research established electrophysiology as a scientific discipline; it also made his career, earning him a seat in the Prussian Academy of Sciences, a professorship in physiology at the University of Berlin, oversight of the Berlin Physiological Society, and Directorship of Berlin's first Institute of Physiology.

Du Bois-Reymond's scientific achievements can be divided between theory, experiment, and technique. With regard to the first category he expounded one of the principal statements of biological reductionism. Du Bois-Reymond conceived of living things as subject to the laws of chemistry and physics, a view expressed most clearly in the introduction to his 1848 treatise on animal electricity. At the time revolution was sweeping through Berlin, and du Bois-Reymond was inspired to draft a kind of scientific manifesto that excoriated the Church, Romantic Naturphilosophie, and any other superstitious believers in the concept of "life force". For his part he claimed to have led to rest the issue of vitalism when he "succeeded in restoring to life, in full reality, the hundred-year-old dream of the physicist and physiologist: the identity of the nervous principle with electricity." [2]

He accomplished this by means of a remarkable series of laboratory investigations [4]. Using a galvanometer, an instrument that could measure faint amounts of electricity, du Bois-Reymond detected a flow of charge through all muscular and nervous tissue. He deemed his finding the "resting current". Far more significant, he discovered that when he stimulated muscles and nerves, the resting current diminished and even reversed. This "negative variation", as he termed it, equates to what we now call the action current - a plain sign of the electrical nature of the nerve signal.

Du Bois-Reymond's breakthroughs rested on a foundation of ingenious and painstaking method. Other scientists had employed galvanometers to investigate animal electricity, but none could rival his patience and skill. To manifest the negative variation in the nerve, for example, du Bois-Reymond spent months designing and constructing the most sensitive galvanometer in existence, one whose coils he wound, by hand, with a mile of wire. He also invented a number of other instruments - dial compensators, sled inductors, nonpolarizable electrodes - some of which remained standard laboratory apparatus well into this century. Indeed it might be said that every subsequent refinement in electrophysiological equipment, from the vacuum tube amplifier to the microelectrode to the patch clamp, can be read as a footnote to du Bois-Reymond's original technique $[5,6]$.

Acknowledgment of du Bois-Reymond's achievements came with time. Scientists in his day, however, remained divided over his significance. This could be seen most clearly in 1850 , when a special commission of the French Academy of Sciences reported on his findings [4]. To his surprise he found his work attacked [7]. A few objections arose from a misunderstanding of his protocol: French physiologists had limited success with instrumentation, and they remained skeptical of its value for over a generation. But other criticisms cut him to the quick. Nearly all of du Bois-Reymond's discoveries were derived from animal preparations, that is to say, muscles and nerves excised from frog legs. The crucial issue regarding this technique was raised by the Academy's report: how could he be sure that the cuts of his 
scalpel were without influence [7]? If this were true the scientific edifice that he had built for a decade would collapse in an instant.

Du Bois-Reymond's method of investigation presumed that parts behaved as wholes: what held for the frog gastrocnemius necessarily held for the entire Rana esculanta. And yet there were times when he saw his supposition fail outright - for example, on a cold day in October, 1843, when he invited a colleague to his apartment to witness the so-called "frog current" and found to his mortification that his galvanometer exhibited no response whatsoever [8]. At first du BoisReymond thought the aberration might be due to electrical activity in the skin that masked the underlying muscle current. This appeared to be the case, since the skin current vanished when he sprayed his frogs with saline (indicating that it did not merely result from a short circuit of the galvanometer leads) and reappeared when he sprayed them with other electrolytes (indicating that it did not merely result from contact electricity). Moreover, removing the surface layer arrested the skin's electrical activity, as did other forms of injury like heat, rot, or desiccation. Du Bois-Reymond noted that the change was permanent: skin removed from a preparation and then replaced over the exposed muscle lost all electromotive power [8].

From this he drew two conclusions. First, moistening frog skin with salt water enabled it to conduct the muscle currents beneath. To reproduce his previous findings he merely needed to keep his electrodes soaked in saline. Second, the slightest irritation vitiated the skin's electrical activity: acids, alkalis, alcohol, acetone, creosote, turpentine, oil, or sugar water introduced into "lymphatic spaces" all occasioned the irreversible result [8]. The only fluids that he tested without effect were blood and lymph [8].

To explain these findings du Bois-Reymond postulated a thin mantle of positive peripolar molecules on the surface of the muscle $[9,10]$. He theorized that this "parelectronomic layer", as he called it, opposed the underlying muscle current normally detectable in laboratory preparations. Depending on its thickness, the parelectronomic layer could diminish or even neutralize the muscle's electromotivity. Furthermore, the layer was extremely labile. Subjecting it to injury destroyed its operation, exposing the current resting in the muscle. Conversely, subjecting it to cold augmented its efficacy. As he had discovered that chilly October morning, and as he later confirmed in the ice cellar of the Royal Veterinary School, low temperatures greatly intensified the condition of parelectronomy [3].
Readers familiar with modern neuroscience might wonder how du Bois-Reymond arrived at this error. After all, was not the parelectronomic condition precisely the null result that should have led him to question his belief in resting muscle currents? And did not the use of injury to restore normal conditions in animal tissue suggest a fundamental misconception of normality? Would it not have been simpler to designate the parelectronomic condition as normal and the resting muscle current as an artifact of experimental violence? In the end, how could he be sure that the cuts of his scalpel were without influence?

In all fairness du Bois-Reymond did consider these possibilities, and his reasons for rejecting them remain sounder than those that discount his decision in hindsight. As he stated in his treatise on animal electricity, he took pains to disprove even the most senseless objections to his theory [3]. For example, to make certain that the muscle current was not caused by a chemical reaction with the metal in his scalpel, he prepared frog legs with his teeth. Biting through muscles left them overly crushed, so he ordered a blade of obsidian from Bötticher and Halske. (The instrument makers had some difficulty replicating this stone-age tool.) He finally came upon a letter opener fashioned out of buffalo horn; this knife corroborated his previous findings [3].

Having eliminated metal as a possible source of electricity, he set about testing whether the muscle current might not derive from the action of a caustic fluid produced from tissue injured by his knife. He reasoned that if this were so, an intact muscle in the parelectronomic state - that is, one evincing no electrical response should develop a current when placed in contact with the cut surface of a fresh muscle. And in countless experiments he observed exactly this [3]. The effect, however, took several minutes to appear. Since normal preparations developed currents immediately after being cut, du Bois-Reymond inferred that the fluid produced by injury could not possibly be the source of electricity in muscles. Instead, as he envisioned it, "artificial cross-sections" through the muscle laid bare a preexisting current hidden by the parelectronomic layer. Any caustic fluid seeping from the cut merely eroded over time the layer that his scalpel had destroyed instantly. With this observation he considered his theory of resting currents verified [3].

Doubts haunted him all the same. Back when he was first investigating animal electricity he attempted to build a physical model of frog muscle [2]. To mimic the electric effect of serried peripolar molecules he soldered strips of zinc to sections of copper tubing that he fixed in rows on a wooden frame [2]. Placing this bat- 
tery in a bath of electrolyte, he measured the distribution of current with his galvanometer. The construction did seem to simulate laboratory findings, but he distrusted the result. "I hardly need to assure the reader that no one can feel more deeply than myself how much this examination leaves to be desired in focus and clarity" [2]. Similar defeats awaited his modification of the model to accord with the theory of parelectronomy [3]. He found the experimental outcome "not entirely satisfactory, insofar as it does not succeed in clearly depicting theoretical expectations. One runs up against unmasterable disturbances from various sides." [3]

Du Bois-Reymond's complaint expressed an increasing sense of disenchantment with his research. The theory of parelectronomy represented the last major battle in his investigations of animal electricity, but rather than conquer new territory it defended old positions. Victory came at a great cost. It took him more than a year and a half before he was able to report his findings to the Prussian Academy of Sciences on 30 June 1851 [8]. Experimenting on chilled frogs proved to be "difficult, time-consuming, and expensive" [3]. Every three or four weeks overwork gave rise to migraine, a horror whose description earned him a place in medical history [1113]. And then there were accidents. Frog skin contained a strong irritant, as he discovered on three separate occasions:

"During the course of my investigations, as I was cutting through an area of skin rich in glands, a tiny drop of the liquid squirted in my eye. By all signs an intense inflammation of the corneal conjunctiva immediately arose, and only after several hours did the incident end with the sloughing off of a layer of epithelium. It is therefore wise to shut the eyes or avert the face whenever frog skin is to be cut." [3]

"Think of me when you read this story in days to come; nothing has ever been as difficult", he wrote his friend, the physiologist Hermann Helmholtz $[9,10]$.

\section{A troublesome student}

Ludimar Hermann, a poor medical student, first met du Bois-Reymond in 1856 [14]. Du Bois-Reymond had reluctantly appointed him lecture assistant, complaining to Helmholtz that only "unskilled Jews" had asked for the position $[15,16]$. Relations improved after Hermann published a textbook of physiology and showed himself to be a promising researcher, so much so that du BoisReymond recommended him in 1865 as the best of his students, "serious, knowledgeable, ambitious, talented, and conscientious" [17].
Disaffection set in two years later. On 5 March 1867 Hermann asked du Bois-Reymond to look over a treatment of animal electricity that he had revised for a new edition of his textbook. "It's not just a question of presentation", he explained, "but more: for some time I've had scruples that no one can clear away as well as you" $[18,19]$. Hermann had hoped to publish his manuscript in du Bois-Reymond's Archiv der Anatomie und Physiologie but withdrew after being advised to reconsider his argument [20]. "Following this", Hermann recalled, "I stuck to my views and continued to work on animal electricity in du Bois-Reymond's laboratory. One day he let me know that he didn't appreciate what I was doing, whereupon I left for good. From that point on he was my bitter enemy...” [21,22]

Hermann's manuscript accused du Bois-Reymond of misconstruing his own experiments [23,24]. Paul Diepgen summarized the charges:

"Hermann attributed the electromotive phenomena of muscle and nerve to processes of chemical decomposition during the gradual death of these organs.... Hermann then developed his theory further ... arriving at the conviction that there was no muscle current at all in intact resting bodies. He said that electromotive phenomena, especially the negative variation, could not be explained by du Bois-Reymond's preexistence theory, his postulation of dipolar molecules in nerve and muscle, and his parelectronomic layer. According to Hermann, these phenomena arose only in dying or active organs as "action currents", since in dying or in activity - which Hermann considered essentially the same chemical process - the affected tissue behaved electrically negative." [25]

In other words, du Bois-Reymond had never detected any real muscle or nerve currents, only the artifacts of tissue injured during preparation. His entire theory of animal electricity would need to be scrapped.

Such criticism did not seem to worry him. Du BoisReymond and his wife took a vacation in the Black Forest early that summer, and he did not rebut his student until mid October, when he delivered a "Refutation of Herr Dr. Ludimar Hermann's Recently Published Theory of Electrical Phenomena in Muscles and Nerves" to the Berlin Academy of Sciences [26-30]. This paper exhibited all his rhetorical brilliance. He began by rehearsing Hermann's argument that muscular contraction and rigor mortis were "one and the same". But as he reminded his readers, "the history of science tells of a hundred seemingly successful aperçus that ultimately have proven just as false". The problem was that Her- 
mann had let his imagination run riot. The idea that animal electricity arose from the progressive decomposition of injured tissue assumed that muscles died from the outside in. Moreover, Hermann could not explain why thick muscles produced stronger currents than thin ones with greater surface areas of decay. Nor was he right to link muscle current to temperature - parelectronomic frogs did not lose their condition in warm rooms, and freezing muscles became alkaline, not acid, as they decomposed. Finally, he could not account for the periodicity of tetanic contractions. Hermann's chemical theory only worked by continually appealing to the saving assumptions of undiscovered phenomena, a device less appropriate to science than to what du Bois-Reymond called "science fiction." [29]

All these errors stemmed from a single observation. Hermann believed that animal electricity originated in tissue injured by the very electrolyte that du BoisReymond had assumed to be harmless. To prove this hypothesis Hermann immersed a frog sartorius part way into a saltwater bath, placing one electrode on the dry surface of the muscle and the other in the saline. He then warmed the solution. When the temperature neared $40^{\circ} \mathrm{C}$ the current suddenly jumped in strength. Cooling the bath lowered the current but failed to return it to its original level [29].

$\mathrm{Du}$ Bois-Reymond checked this experiment ten times. Unlike Hermann he witnessed no initial muscle current. Warming the saline did indeed produce a signal, but one so slight as to be indistinguishable from thermoelectricity. Furthermore, the current did not sink when the solution cooled, and neither was it stronger than that produced by an artificial cross-section. Du BoisReymond's conclusion was harsh:

“Hermann's hypothesis that animal electricity originates in chemical processes connected with the injury of artificial cross-sections is theoretically unjustified; it lacks clarity, certainty, and consistency; not to speak of any analogy in fact, with the exception of a single shaky experiment. It explains little more than the observations for whose explanation it was invented; for the explanation of other equally important observations it has to seek recourse in circular reasoning and ad hoc hypotheses that prove in part false, in part theoretically unjustified, and in part without any basis in current knowledge." [29]

Consequently, du Bois-Reymond determined to stick with his molecular hypothesis until a better alternative was found. He claimed even more certainty for "the preexistence of electrical differences in muscles and nerves": any proof to the contrary left him with the unpleasant feeling of "laboring under a misapprehension" [29].

Doubts plagued him anyway, just as they had after his rebuke by the French Academy of Sciences, and he devoted November and December to checking his experiments [31]. The chemist Henry Bence Jones, an English friend and longtime supporter, tried to put a good face on his effort:

"I am very sorry to hear of the doings of your beloved pupil. His theory is very pretty \& the time it must have cost you to demolish it might have been far better spent on new work, which would have been far pleasanter than going over the old ground again. However it is not lost work \& new ideas will come out of the discussion which will make the truth more clear than ever. Hermann is not likely to find you making any mistake in your experiments \& if there is any mistake in his you will find it out I am sure, but I wish you had pleasanter work than a controversy with an old assistant." [32]

In the meantime du Bois-Reymond invited Hermann back to his laboratory. His student thanked him for his offer and let him know that he had conducted all his contentious experiments at home. Now that he had finished the third revision of his treatise, he asked du BoisReymond to consider publishing it in his journal. At the very least this would demonstrate that their polemic was not personal. To smooth things over he offered to go through the manuscript with him in person [33,34].

Du Bois-Reymond perused Hermann's corrections in dismay. Hermann had ignored his criticism, condescending only to restate previous arguments and blame du Bois-Reymond's errors on outworn technique [35]. To top it off he asked for a letter of recommendation for a position opening in Zurich. When du Bois-Reymond declined in favor of Isidor Rosenthal, another one of his students, Hermann complained to colleagues that he had been blackballed. "Now Hermann has added delusions of persecution to his delusions of grandeur", du Bois-Reymond wrote to Helmholtz. "His accusations are untrue, as you can well imagine. Not exactly noble of him, considering how generous I've been from the very start with laboratory space and anything else that could help him. His paper was one of the worst pieces of work that has ever been written." [36] Whatever the truth of this statement, Hermann's allegations did not stand him well. Helmholtz criticized his "premature generalizations" and his "rash craving for status", and another physiologist, Carl Ludwig, reproved 
"his doctrinaire character and his inclination to overestimate his own hypotheses" [37,38]. Still, it is hard not to hear similar notes of vanity in a testimonial that du Bois-Reymond sent to Ludwig in July:

"If it is true that Fick is leaving Zurich, and you are still able to exert some influence there, recommend Rosenthal. A long-term assistant ends up the most inconvenient fixture precisely because he is the most convenient. Every improvement I make implies, in his eyes, that I have done it poorly hitherto. I cannot take out of his hands the experiments he does not do as well, and naturally I cannot do so with the experiments he does better... This has given him an influence, passed on from one semester to the next, that overshadows my own. As you see, these things make me want to part company but do not speak against him in the least. They are grievances grown out of the inconvenience of his remaining stuck in a position suitable only for a younger, flexible, sufficiently subservient man. I am quite convinced that he is a very good, versatile teacher who will do great credit to a recommendation." [39]

As it turned out Zurich picked Hermann. On 5 October 1868 he wrote to du Bois-Reymond that he was leaving Berlin and wanted to say goodbye. Du BoisReymond thanked him for his words of friendship, adding that he had never considered his writings hostile and accusing anyone who insinuated the contrary of lying. He felt that it would be better if they did not meet: now that they had written to each other, nothing more could come of the encounter than unpleasantness [40]. The two scientists did not correspond again until 1889. They never saw eye to eye [41-44].

\section{Conclusion}

What are we to make of this dispute? At bottom it seems to reduce to differences in opinion. Du Bois-Reymond's closest friend, the physiologist Ernst Brücke, once reminded him that it was "against their principles" to engage in polemics with former teachers [45]. Du Bois-Reymond would never have thought of crossing his advisor Johannes Müller. Hermann had shown no such restraint. "From the time I trained him in my laboratory", du Bois-Reymond noted in an unpublished composition, "Hr. Hermann has pursued, with an energy that he might have put to better scientific and ethical use, the goal of toppling my theory of muscle and nerve currents in order to raise his new theory on the ruins" [22]. Du Bois-Reymond had good reason to feel defensive: he had watched "significant thunderclouds" gathering above his theoretical edifice since 1859. "If my supposed discoveries really only do last for a few years, I console myself with the thought that they at least have aroused some interest. But I would have liked to have been the one to detect the error" [46]. Instead, he had been beset with "a young man who did not scruple to undertake - in my laboratory - with my instruments investigations that would spell my scientific downfall in the case of their success" [22]. Du Bois-Reymond did not believe this to have occurred. Hermann had never shown him to have made a false observation, and du Bois-Reymond remained convinced that his opponent's interpretations erred in significance and prediction [22].

At least this was how he felt in 1876, the year he published his final refutation of Hermann's theory [47]. As time went on du Bois-Reymond grew less sure of himself. He had never shied from admitting his mistakes, and by the end of his life he taught his students that evidence seemed to favor Hermann [48-50]. Six years after his death Julius Bernstein proposed an innovative "membrane theory" of nervous transmission. Using the concept of ion diffusion developed by Walther Nernst and Wilhelm Ostwald, Bernstein correlated theoretical predictions of electrical potential with measurements of resting current in nerve fibers. He was thus able to rescue du Bois-Reymond's belief in "the preexistence of electrical differences in muscles and nerves", albeit in terms of potential rather than current. Additional studies of the temperature dependence of muscle and nerve currents convinced him of his teacher's objections to Hermann's metabolic hypotheses; however, parts of Hermann's explanation of negative variation figured into Bernstein's final account of nerve signals [51-55]. As with many scientific controversies, resolution appeared in the form of a novel synthesis.

Naïve historians equate rebellion with progress, as if every break with the past necessarily anticipated the future. Their histories express a curious sympathy towards du Bois-Reymond's rivals Carlo Matteucci and Ludimar Hermann absent in their treatments of du BoisReymond. Losers are not always underdogs, though. Du Bois-Reymond had good reason to reject Hermann's chemical theory. Chemistry simply did not offer the same power of explanation as physics for most of the nineteenth century. As late as 1882 du Bois-Reymond's review of the discipline still looked expectantly to the future [56]. It took decades of analysis from Ostwald to Pauling before the 'Newtons of chemistry' imagined by du Bois-Reymond finally reduced chemical 'qualities' to mathematical equations [56,57]. Du Bois-Reymond's preference for physical theory expressed a profound conservative truth: it is better to stick with the limita- 
tions of known models than to gamble on the promises of the unknown. Du Bois-Reymond understood that all systems of organization were provisory - what mattered was that they worked in practice. Consider his critique of Rousseau:

\section{"The mistake in Rousseau's thinking that led him astray in his speculations, even with all his keen perception, hard work, and good will-for despite Grimm's suspicions, we do not wish to doubt the last - was radicalism, our term for rationalism in politics, administration, education, and similar prac- tical endeavors. It appears as the inclination to make ideal assumptions and to apply abstract schemata in judging complex human relations, rather than tak- ing into account the real, half-natural, half-historical conditions - human nature with its passions, idiosyn- crasies, habits, and faults - and investigating the hid- den psychological forces that drive human action." [58]}

This is a wise testament to the limitations of achievement, science above all.

\section{References}

[1] G. Finkelstein, The ascent of man? E. du-Bois Reymond's reflections on scientific progress, Endeavour 24 (2000) 129-132.

[2] E. du-Bois Reymond, in: Untersuchungen über thierische Elektricität, vol. 1, Reimer, Berlin, 1848-1884.

[3] E. du-Bois Reymond, in: Untersuchungen über thierische Elektricität, vol. 2, Reimer, Berlin, 1848-1884.

[4] G. Finkelstein, M. du Bois-Reymond goes to Paris, Br. J. Hist. Sci. 36 (2003) 261-300.

[5] R.G. Frank Jr., Instruments, nerve action, and the all-or-nothing principle, Osiris, 2nd ser. 9 (1994) 208-235.

[6] E. Neher, B. Sakmann, The Patch clamp technique, Sci. Am. 266 (1992) 44-51.

[7] C. Pouillet, et al., Rapport sur les Mémoires relatifs aux phénomènes électrophysiologiques présentés à l'Académie par M.E. du Bois-Reymond (de Berlin), C. R. Acad. Sci. Paris 31 (1850) 28-47.

[8] E. du-Bois Reymond, Fortsetzung der Untersuchungen über thierische Elektrizität, Bericht über die zur Bekanntmachung geeigneten Verhandlungen der Königl. Preuß, Akademie der Wissenschaften zu Berlin, 1851, pp. 380-398.

[9] E. du-Bois Reymond to H. Helmholtz, 19 March 1850, in: C. Kirsten (Ed.), Dokumente einer Freundschaft. Briefwechsel zwischen Hermann von Helmholtz und Emil du Bois-Reymond 1846-1894, Akademie-Verlag, Berlin, 1986, pp. 92-94.

[10] E. du-Bois Reymond to H. Helmholtz, 25 August 1850, in: C. Kirsten (Ed.), Dokumente einer Freundschaft. Briefwechsel zwischen Hermann von Helmholtz und Emil du Bois-Reymond 1846-1894, Akademie-Verlag, Berlin, 1986, pp. 98-100.

[11] E. du-Bois Reymond, Zur Kenntniss der Hemikrania. Aus einem in der Gesellschaft für Natur- und Heilkunde am 1. März 1859 gehaltenen Vortrage, Archiv für Anatomie, Physiologie und wissenschaftliche Medicin (1860) 461-468.
[12] P.J. Koehler, Brown-Séquard's comment on Du Bois-Reymond's 'Hemikrania Sympathicotonica', Cephalalgia 15 (1995) 370372.

[13] J.M.S. Pearce, Historical note: Emil Heinrich Du Bois-Reymond (1818-1896), J. Neurol., Neurosurg. Psychiatry 71 (2001) 620.

[14] T. Otto, Ludimar Hermann (1838-1914) und E. du-Bois Reymond (1818-1896), Ein Streit um die vitalisierende Kraft der Elektrizität, M.A. thesis, Technische Universität, Berlin, 1995.

[15] E. du-Bois Reymond to H. Helmholtz, 26 October 1856, in: C. Kirsten (Ed.), Dokumente einer Freundschaft. Briefwechsel zwischen Hermann von Helmholtz und Emil du Bois-Reymond 1846-1894, Akademie-Verlag, Berlin, 1986, pp. 162-165, on 163.

[16] L. Hermann, Erinnerungen, privately printed, Berlin, 1915, p. 21, in: J.H. Schawalder, Der Physiologe Ludimar Hermann (18381914). Berlin-Zürich-Königsberg, Juris Verlag, Zurich, Switzerland, 1990, pp. 8-9.

[17] E. du-Bois Reymond to H. Helmholtz, 18 February 1865, in: C. Kirsten (Ed.), Dokumente einer Freundschaft. Briefwechsel zwischen Hermann von Helmholtz und Emil du Bois-Reymond 1846-1894, Akademie-Verlag, Berlin, 1986, pp. 216-217.

[18] L. Hermann, Grundriss der Physiologie des Menschen, Hirschwald, Berlin, 1863

[19] L. Hermann to E. du-Bois Reymond, 5 March 1867, in: T. Otto, Ludimar Hermann (1838-1914) und E. du-Bois Reymond (1818-1896), Ein Streit um die vitalisierende Kraft der Elektrizität, M.A. thesis, Technische Universität, Berlin, 1995, p. 90.

[20] L. Hermann to E. du-Bois Reymond, 17 July 1867, in: T. Otto, Ludimar Hermann (1838-1914) und E. du-Bois Reymond (1818-1896), Ein Streit um die vitalisierende Kraft der Elektrizität, M.A. thesis, Technische Universität, Berlin, 1995, p. 90.

[21] L. Hermann, Erinnerungen, privately printed, Berlin, 1915, p. 57, in: J.H. Schawalder, Der Physiologe Ludimar Hermann (18381914). Berlin-Zürich-Königsberg, Juris Verlag, Zurich, Switzerland, 1990, pp. 11-12.

[22] E. du-Bois Reymond, "Gegen Ludimar Hermann", Staatsbibliothek Preussischer Kulturbesitz zu Berlin, Haus 2, Handschriften Abteilung, Nachlaß Emil du Bois-Reymond, K. 11, M. 9, B1. 1-7.

[23] L. Hermann, Untersuchungen über den Stoffwechsel der Muskeln, ausgehend von Gaswechsel derselben, Hirschwald, Berlin, 1867.

[24] L. Hermann, Weitere Untersuchungen zur Physiologie der Muskeln und Nerven, Hirschwald, Berlin, 1867.

[25] P. Diepgen, in: P.F. Cranefield (Ed.), E. du Bois-Reymond, Two great scientists of the nineteenth century. Correspondence of Emil du Bois-Reymond and Carl Ludwig, S. Lichtner-Ayèd (tr.), The Johns Hopkins University, Baltimore, London, 1982, p. 156, n. 225 (my translation).

[26] E. du-Bois Reymond to H. Helmholtz, 25 April 1867, in: C. Kirsten (Ed.), Dokumente einer Freundschaft. Briefwechsel zwischen Hermann von Helmholtz und Emil du Bois-Reymond 1846-1894, Akademie-Verlag, Berlin, 1986, pp. 224-226.

[27] E. du-Bois Reymond to H. Helmholtz, 1 June 1867, in: C. Kirsten (Ed.), Dokumente einer Freundschaft. Briefwechsel zwischen Hermann von Helmholtz und Emil du Bois-Reymond 1846-1894, Akademie-Verlag, Berlin, 1986, pp. 226-227.

[28] H. Helmholtz to E. du-Bois Reymond, 2 June 1867, in: C. Kirsten (Ed.), Dokumente einer Freundschaft. Briefwechsel zwischen Hermann von Helmholtz und Emil du Bois-Reymond 1846-1894, Akademie-Verlag, Berlin, 1986, p. 227.

[29] E. du-Bois Reymond, Widerlegung der von Hrn. Dr. Ludimar Hermann kürzlich veröffentlichen Theorie der elektromo- 
torischen Erscheinungen der Muskeln und Nerven. Gelesen in der Sitzung der physikalisch-mathematischen Klasse der Königl. Akademie der Wissenschaften zu Berlin am 14. Oktober 1867, in: Gesammelte Abhandlungen zur allgemeinen Muskel- und Nervenphysik, vol. 2, Veit \& Co., Leipzig, 1875-1877, pp. 319363.

[30] E. du-Bois Reymond to L. Hermann, 22 October 1867, in: T. Otto, Ludimar Hermann (1838-1914) und E. du-Bois Reymond (1818-1896), Ein Streit um die vitalisierende Kraft der Elektrizität, M.A. thesis, Technische Universität, Berlin, 1995, pp. 9091.

[31] E. du-Bois Reymond, Contra Hermann, 6 November-14 December 1867 , laboratory notebooks, Staatsbibliothek Preussischer Kulturbesitz zu Berlin, Haus 2, Handschriften Abteilung, Nachlaß Emil du Bois-Reymond, K. 10, Nr. 13, B1. 48-56.

[32] H.B. Jones to E. du-Bois Reymond, 6 January 1868, Staatsbibliothek Preussischer Kulturbesitz zu Berlin, Haus 2, Handschriften Abteilung, SD 3k 1852 (3), B1. 388-390.

[33] L. Hermann to E. du-Bois Reymond, 5 January 1868, in: T. Otto, Ludimar Hermann (1838-1914) und E. du-Bois Reymond (1818-1896), Ein Streit um die vitalisierende Kraft der Elektrizität, M.A. thesis, Technische Universität, Berlin, 1995, p. 91.

[34] L. Hermann to E. du-Bois Reymond, 15 March 1868, in: T. Otto, Ludimar Hermann (1838-1914) und E. du-Bois Reymond (1818-1896), Ein Streit um die vitalisierende Kraft der Elektrizität, M.A. thesis, Technische Universität, Berlin, 1995, p. 91.

[35] L. Hermann, Untersuchungen zur Physiologie der Muskeln und Nerven. Drittes Heft. Ueber die Ursache der elektromotorischen Erscheinungen an Muskeln und Nerven. Anhang. Ueber Ströme an einigen thierischen Theilen, die dem Muskel- und Nervensystem nicht angehören, Hirschwald, Berlin, 1868.

[36] E. du-Bois Reymond to H. Helmholtz, 25 April 1868, in: C. Kirsten (Ed.), Dokumente einer Freundschaft. Briefwechsel zwischen Hermann von Helmholtz und Emil du Bois-Reymond 1846-1894, Akademie-Verlag, Berlin, 1986, pp. 229-230.

[37] H. Helmholtz to E. du-Bois Reymond, 20 April 1868, in: C. Kirsten (Ed.), Dokumente einer Freundschaft. Briefwechsel zwischen Hermann von Helmholtz und Emil du Bois-Reymond 1846-1894, Akademie-Verlag, Berlin, 1986, p. 228.

[38] C. Ludwig to President of the University of Zurich Search Committee, 2 August 1868, in: J.H. Schawalder, Der Physiologe Ludimar Hermann (1838-1914). Berlin-Zürich-Königsberg, Juris Verlag, Zurich, Switzerland, 1990, pp. 12-13.

[39] E. du-Bois Reymond to C. Ludwig, 17 July 1868, in: P.F. Cranefield (Ed.), E. du Bois-Reymond, Two great scientists of the nineteenth century. Correspondence of Emil du Bois-Reymond and Carl Ludwig, S. Lichtner-Ayèd (Tr.), The Johns Hopkins University, Baltimore, London, 1982, pp. 104-105 (my translation).

[40] E. du-Bois Reymond to L. Hermann, 7 October 1868, in: T. Otto, Ludimar Hermann (1838-1914) und E. du-Bois Reymond (1818-1896), Ein Streit um die vitalisierende Kraft der Elektrizität, M.A. thesis, Technische Universität, Berlin, 1995, p. 91.

[41] L. Hermann to E. du-Bois Reymond, 17 September 1889, in: T. Otto, Ludimar Hermann (1838-1914) und E. du-Bois Reymond (1818-1896), Ein Streit um die vitalisierende Kraft der Elektrizität, M.A. thesis, Technische Universität, Berlin, 1995, p. 92.

[42] L. Hermann to E. du-Bois Reymond, 27 September 1889, in: T. Otto, Ludimar Hermann (1838-1914) und E. du-Bois Reymond (1818-1896), Ein Streit um die vitalisierende Kraft der Elektrizität, M.A. thesis, Technische Universität, Berlin, 1995, p. 92 .
[43] L. Hermann to E. du-Bois Reymond, 17 July 1892, in: T. Otto, Ludimar Hermann (1838-1914) und E. du-Bois Reymond (1818-1896), Ein Streit um die vitalisierende Kraft der Elektrizität, M.A. thesis, Technische Universität, Berlin, 1995, p. 92.

[44] L. Hermann to E. du-Bois Reymond, 5 February 1893, in: T. Otto, Ludimar Hermann (1838-1914) und E. du-Bois Reymond (1818-1896), Ein Streit um die vitalisierende Kraft der Elektrizität, M.A. thesis, Technische Universität, Berlin, 1995, pp. 9293.

[45] E. Brücke to E. du-Bois Reymond, 23 May 1853, in: H. Brücke, W. Hilger, W. Höflechner, W.W. Swoboda (Eds.), in: Briefe an Emil du Bois-Reymond, vol. 1, Akademische Druck- u. Verlagsanstalt, Graz, Austria, 1978, pp. 58-59.

[46] E. du-Bois Reymond to C. Ludwig, 18 December 1859, in: P.F. Cranefield (Ed.), E. du Bois-Reymond, Two great scientists of the nineteenth century. Correspondence of Emil du BoisReymond and Carl Ludwig, S. Lichtner-Ayèd (tr.), The Johns Hopkins University, Baltimore, London, 1982, p. 101.

[47] E. du-Bois Reymond, Widerlegung der Hermann'sche Theorie der negativen Schwankung und Untersuchung letzterer bei unmittelbarer Reizung curarisirter Muskeln, in: Gesammelte Abhandlungen zur allgemeinen Muskel- und Nervenphysik, vol. 2, Veit \& Co., Leipzig, 1875-1877, pp. 566-591.

[48] E. du Bois-Reymond, Über das Gesetz des Muskelstromes, in: Gesammelte Abhandlungen zur allgemeinen Muskel- und Nervenphysik, vol. 2, Veit \& Co., Leipzig, 1875-1877, pp. 63-187, on $126-127$.

[49] E. du Bois-Reymond, Über die Negative Schwankung des Muskelstromes bei der Zusammenziehung. Erste Abtheilung, in: Gesammelte Abhandlungen zur allgemeinen Muskel- und Nervenphysik, vol. 2, Veit \& Co., Leipzig, 1875-1877, pp. 402-483, on $420-423$.

[50] C. Mohr (Ed.), Compendium der Physiologie für die medizinischen Prüfungen. Unter Anlehnung an die Vorlesungen von weiland Geh. Rat Professor Dr. E. Du Bois-Reymond in Berlin, Verlag von H. Hartung \& Sohn, Leipzig, Germany, 1901, p. 180.

[51] J. Bernstein, Untersuchungen zur Thermodynamik der bioelektrischen Ströme, Pflügers Archiv 92 (1902) 521-562.

[52] J. Bernstein, Elektrobiologie. Die Lehre von den elektrischen Vorgängen im Organismus auf moderner Grundlage dargestellt, Vieweg \& Sohn, Braunschweig, Germany, 1912.

[53] A. Tschermak, Julius Bernsteins Lebensarbeit. Zugleich ein Beitrag zur Geschichte der neueren Biophysik, Pflügers Archiv 174 (1919) 1-89.

[54] T. Lenoir, Models and instruments in the development of electrophysiology, HSPS 17 (1986) 1-54.

[55] E.A. Seyfurt, L. Peichl, Vor 100 Jahren: Julius Bernstein (18391917) formuliert seine 'Membrantheorie', Neuroforum 4 (2002) 274-276.

[56] E. du-Bois Reymond, Antwort auf die in der Leibnitz-Sitzung der Akademie der Wissenschaften am 29. Juni 1882 gehaltene Antrittsrede des Hrn. Hans Landolt, in: E. du Bois-Reymond (Ed.), Reden von Emil du Bois-Reymond, vol. 2, Veit \& Comp., Leipzig, Germany, 1912, pp. 610-615.

[57] J.W. Servos, Physical chemistry from Ostwald to Pauling. The Making of a science in America, Princeton University, Princeton, NJ, USA, 1990.

[58] E. du Bois-Reymond, Friedrich II und Jean-Jacques Rousseau. In der Friedrichs-Sitzung der Akademie der Wissenschaften am 30. Januar 1879 gehaltene Rede, in: E. du Bois-Reymond (Ed.), Reden von Emil du Bois-Reymond, vol. 2, Veit \& Comp., Leipzig, Germany, 1912, p. 15. 